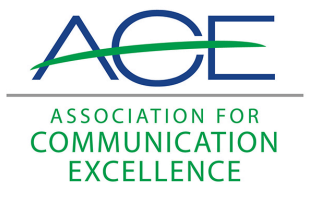

Journal of Applied Communications

\title{
An Exploration of Consumer Perceptions of Plants and Plant Characteristics: A Qualitative Study of Florida Plant and Garden Consumers
}

Kathryn Wilson

Carly Barnes

Tracy Irani

\section{Recommended Citation}

Wilson, Kathryn; Barnes, Carly; and Irani, Tracy (2013) "An Exploration of Consumer Perceptions of Plants and Plant Characteristics: A Qualitative Study of Florida Plant and Garden Consumers," Journal of Applied Communications: Vol. 97: Iss. 3. https://doi.org/10.4148/1051-0834.1113

This Research is brought to you for free and open access by New Prairie Press. It has been accepted for inclusion in Journal of Applied Communications by an authorized administrator of New Prairie Press. For more information, please contact cads@k-state.edu. 


\title{
An Exploration of Consumer Perceptions of Plants and Plant Characteristics: A Qualitative Study of Florida Plant and Garden Consumers
}

\author{
Abstract \\ When planning and developing a state-specific agricultural product brand and marketing campaign, it is \\ important to consider potential consumers' perceptions of terminology, messages, and attitudes toward \\ the product. This qualitative study explores Florida consumer perceptions of green industry terminology, \\ such as "plant," "garden," "landscape," and "home landscape" as well as plant characteristics important to \\ consumer purchase. Participants in all six of the Florida-based focus groups utilized in this study did not \\ feel that a brand was important to plant purchase. Given the findings in of the study, recommendations \\ for marketing an agricultural product of this nature include using the word "plant" over "garden;" achieving \\ the plant characteristics deemed to be the most important to plant purchases (healthy-looking, quality, \\ and 'makes me feel good') with the product; and emphasizing these characteristics in a well-targeted \\ marketing campaign.
}

\section{Keywords}

Florida gardening, Florida plant/garden consumers, branding, plant characteristics 


\section{An Exploration of Consumer Perceptions of Plants and Plant Characteristics: A Qualitative Study of Florida Plant and Garden Consumers}

\section{Kathryn Wilson, Carly Barnes and Dr. Tracy Irani}

\section{Abstract}

When planning and developing a state-specific agricultural product brand and marketing campaign, it is important to consider potential consumers' perceptions of terminology, messages, and attitudes toward the product. This qualitative study explores Florida consumer perceptions of green industry terminology, such as "plant," "garden," "landscape," and "home landscape" as well as plant characteristics important to consumer purchase. Participants in all six of the Florida-based focus groups utilized in this study did not feel that a brand was important to plant purchase. Given the findings in of the study, recommendations for marketing an agricultural product of this nature include using the word "plant" over "garden;" achieving the plant characteristics deemed to be the most important to plant purchases (healthy-looking, quality, and "makes me feel good') with the product; and emphasizing these characteristics in a well-targeted marketing campaign.

\section{Keywords}

Florida gardening, Florida plant/garden consumers, branding, plant characteristics

\section{Introduction}

Agriculture can be a difficult market for American growers and producers. Given appreciating land values, high input costs, the need to harvest at the peak of ripeness, and strict industry regulations, farmers can easily incur financial losses (Adelaja, 1996). Policymakers and industry representatives are constantly looking for a way to help growers and producers to remain economically viable businesses in the agriculture sector (Govindasamy \& Nayga, 1996). In response, many states have turned to state-specific marketing campaigns for their agricultural products. For example, many state's Department of Agriculture agencies have sponsored or supported the development of statespecific brands to boost sales and consumer recognition. State-specific agricultural products promoted throughout the United States commonly include meat, dairy, produce, and aquaculture, as well as non-consumable goods such as horticultural products.

When considering marketing an agricultural product, there are many important considerations. Agricultural products are primarily marketed as commodities. Commodities, defined as economic goods, have a demand but a general lack of qualitative differentiation, such as a brand. In horticulture, the branding of products is rather rare. However, the branding of agricultural and horticultural products enables consumers to identify a specific product, especially if it offers the buyer added value in the form of a quality guarantee; consumer loyalty and price premiums could be expanded with the 
implementation of successfully marketed brands (Koelemeijer, Luetscher, \& Stoeken, 1993). Once a brand is well established, it has the ability to provide a differentiated product that increases the added value for the producer (Bagnara, 1996).

Given that there is such a low proportion of the American public directly engaged in agriculture as well as the tendency of agricultural products not easily lending to branding, consumers are crucial to a successful marketing campaign. Testing potential consumers' perceptions of words, phrases, designs, and communication materials before engaging in a marketing campaign helps ensure that consumers will respond favorably and have a clear understanding of the product.

The Florida Nursery, Growers and Landscape Association (FNGLA), a large state commodity member organization, began developing plants to market a state-specific plant brand in 2009. The Florida Garden Select brand is a program designed to encourage the use of "superior and proven" Florida plants (FNGLA, 2011). Florida Garden Select plants are promoted as being ideal plants for most Florida gardens. Many of the selected plants are marketed outside Florida and into most Southern States. A hardiness zone feature is emphasized to locate plants specific to each growing zone (FNGLA, 2011).

Several Southern states, including Georgia, Kentucky, Louisiana, Mississippi, Oklahoma, and Texas, have implemented state-specific plant promotion programs with the goals of identifying specific plants and generating awareness of these plants through a state-wide promotional marketing campaign to increase sales through price premiums (Steglin, Turner, \& Knight, 2001). Though there are many similarities between the programs in regard to creation, funding, governance, and marketing strategies, there are also many differences, and there has been very little formal monitoring and/ or oversight to evaluate if the programs actually achieve their goals (Stegelin et al., 2001).

While some state plant branding programs have conducted consumer recognition and satisfaction surveys after the fact, most have not utilized message or communication material testing prior to launching the brand (Dr. Charlie Hall, Ellison Chair in International Floriculture at Texas A\&M University, personal communication, 11/15/2010). This study, conducted prior to launching a campaign, could have great implications for organizations interested in state branding and marketing campaigns.

Understanding potential consumers' perceptions of plants and gardening, as well as plant purchase patterns, can assist green industry companies in more effectively marketing their products. Based on the above, the purpose of this study is to explore the significance of a plant brand by utilizing focus groups comprised of Florida consumers of home and garden products. Objectives included exploring consumer perceptions of words, terms, and phrases associated with plants and gardening and determining the plant characteristics most important to consumers' decisions to purchase.

\section{State plant promotional programs}

New Jersey implemented the first state-funded marketing program for agricultural products in 1984 with its Jersey Fresh campaign. This program was designed to generate consumer awareness of agricultural products in New Jersey, as well as to promote Jersey Fresh products among food retailers (Govindasamy, 2003). In a 2003 study, 77.5 percent of randomly selected consumers in New Jersey recognized the Jersey Fresh logo, as well as 50 percent of randomly selected consumers in New York and 30 percent in Pennsylvania (2003). Over its 26-year campaign period, Jersey Fresh has utilized several taglines and a variety of advertising mediums (2003). Research indicates that for every dollar contributed to the Jersey Fresh program through 2000, agricultural fruit and vegetable revenues 
increased by $\$ 31.54$. The Jersey Fresh program is estimated to contribute $\$ 63.2$ million to the state economy (2003).

Florida also implements a statewide agricultural marketing campaign, Fresh from Florida, through its Florida Agricultural Promotional Campaign (FAPC). The FAPC is described as "an identification and promotional program designed to boost the image of Florida agriculture and increase sales by helping consumers easily identify Florida agricultural products" (Florida Department of Agriculture and Consumer Services, 2004). Members of Florida's agriculture industry can join the FAPC campaign and have access to the Fresh from Florida logos, be listed on the state's Agricultural Product Search website, receive graphic assistance, and other benefits of membership (2004). The Fresh from Florida logo and campaign is used across the department's divisions, and is included on communications materials and websites (2004). The logo and campaign has also been extended to commodity groups, such as the Fresh from Florida Seafood campaign (Florida Department of Agriculture and Consumer Services Division of Marketing, 2004).

In addition to statewide agricultural marketing campaigns, some states have implemented statewide marketing campaigns specific to the plant and horticulture industry. Florida is not the only state to implement a plant promotion program. Many states have introduced horticulture product brands programs that feature varieties either native or beneficial to the area, or at least known to thrive in the specific climate. State and regional branding has also allowed consumers to associate ornamental products to a particular geographical region (Lillywhite et al., 2005).

Steglin, Turner, and Knight (2001) conducted an evaluation of state plant promotion programs in Southern states that indicates that most states employ a brand for a plant promotion program, such as Georgia's Georgia Gold Medal Winner ${ }^{\mathrm{TM}}$ and Mississippi's Mississippi Medallion ${ }^{\mathrm{TM}}$. The development of these state programs included university program sponsorship, plant selection committees and criteria, goals for promotion, and coordination with the industry.

Texas's Texas Superstar ${ }^{\mathrm{TM}}$ plant branding program is an example of a long-term plant brand that is meeting its objectives of increasing producer profits, but has only recently been evaluated for customer awareness and willingness to pay. This brand was initially locally and regionally promoted by a popular Extension horticulturist known in the San Antonio area before Texas A\&M University encouraged participants to develop a statewide promotional program (Dr. Charlie Hall, Ellison Chair in International Floriculture at Texas A\&M University, personal communication, 11/15/2010).

Despite the significant investments in research and marketing, no message testing or consumer awareness research was conducted prior to launching the Texas program (Collart, Palma, \& Hall, 2010). A recently published evaluation of the Texas Superstar program in relation to consumer behavior demonstrated that though the consumer awareness of the brand is low, the level of satisfaction among consumers is high (Collart et al., 2010). Consumers who frequently shopped for plants or previously knew of the brand were more likely to purchase a Texas Superstar plant; the products were successful at creating a price premium and the willingness to pay for a Texas Superstar was found to be 10 percent higher than an unbranded plant (Collart et al., 2010).

\section{Theoretical Framework}

The theories guiding this study include those relevant to branding a commodity. These theoretical frameworks include Schema Theory, the Model of Causality in Social Learning, the Theory of Planned Behavior, and the Elaboration Likelihood Model. 


\section{Schema Theory}

Schema theory explains the linkages between symbols and meaning by taking in the totality of an individual's life experiences (Reichel, 2009). "Because schemata are anticipations, they are the medium by which the past affects the future; information already acquired determines what will be picked up next"(Neisser, 1976, p. 74). Rumelhart refers to schemata as the "building blocks of cognition" (1980, p. 33) and argues that schemata are used in interpreting both linguistic and nonlinguistic sensory data.

Neisser's (1976) concept of pattern recognition involves assigning categories to objects or other stimuli and the higher levels of comprehension and processing can be explained by schema theory (Reichel, 2009). Rumelhart (1980) describes schemata as "the fundamental elements upon which all information processing depends" (p. 33). Therefore, schema theory can be utilized to understand the importance of a purchaser's past life experiences to the purchaser's attitude toward buying a product and their decision to purchase. The cognitive information ascribed to objects or stimuli based on an individual's past experiences could influence purchasing decisions in terms of the individual's schemata associated with a product, brand, or message. For example, in this study, participants were asked to rate what was most important when making plant purchases, and utilized various schemas, or cognitive shortcuts, to identify what plant characteristics were most essential to purchase decisions.

\section{Model of Causality in Social Learning}

The Model of Causality in social learning explores the relationships between human behavior, cognitive and internal activities, and the external environment (Bandura, 1985). The favored concept of interaction in social learning theory is triadic reciprocality, in which behavior, cognitive and internal activities or personal factors, and external environmental influences are viewed as interdependent determinants that influence each other bidrectionally (Bandura, 1985). In terms of marketing and branding horticultural products, the Model of Causality in Social Learning can be utilized to understand the influence of the purchaser's previous knowledge and perceptions of the product on the purchaser's decision to buy a product, as well as the influence of the external environment on the purchaser's cognitive and internal activities, or the purchaser's thoughts or attitude toward buying a particular product.

\section{Theory of Planned Behavior}

Regarding desired consumer changes in attitude or behavior, the Theory of Planned Behavior addresses behavior intent, normative influences, perceived behavioral control, and sense of efficacy as the primary influences upon behavior (Ajzen, 1991). In this theory, human behavior is guided by behavioral, normative, and subjective beliefs (Ajzen, 2002). If the objective is to encourage consumers to purchase a state plant brand, consumers should have the intention to support the brand, know other people who think it is important and/or a good product, know that the product is available, and think that the purchase will benefit them personally, or help their community or state's economy in a significant way.

\section{Elaboration Likelihood Model}

The Elaboration Likelihood Model (ELM) is a general theory of attitude that posits that there are basically two routes to persuading a target audience: the central route, through carefully and thoughtfully assessing the merits of contrived arguments and information, or the peripheral route, 
which entails some kind of cognitive or behavioral cue that infers the argument without the complex processing of information, which is more of an "attractive source" (Petty \& Cacioppo, 1986). The more complex central route is known to be the least preferred information processing activity as it requires more exertion and attention, but this is dependent on individual and situational factors (Frewer, Howard, Hedderley, \& Shepherd, 1997). Also, the degree to which the information is salient or relevant to the individual determines whether they will use the central or peripheral routes. If it is highly personal, the individual will be more likely to spend the time and energy required to determine the merits of the information; if the information is relatively salient and the source is thought to be credible, the peripheral route may be deemed adequate (Frewer et al., 1997). In the case of marketing a state-specific plant brand, messages will be more likely to be retained and trusted if they are made to seem relevant to potential consumers and they come from a trusted source.

\section{Purpose and Objectives}

The purpose of this study was to better understand Florida consumers' perceptions of plant brands in relation to plants selected for purchase. In order to test messages and communication materials developed for "Florida Garden Select," a Florida-specific plant brand, FNGLA partnered with the University of Florida/Institute of Food and Agricultural Sciences' (UF/IFAS) Center for Public Issues Education in Agriculture and Natural Resources (PIE Center) to conduct focus groups with potential consumers around the state.

The objectives that were used to guide the research were to: 1) explore consumers' perceptions of terms related to plants, gardening, and landscaping, and to 2) determine what types of messages and plant characteristics consumers' best respond to in relation to purchasing plants.

\section{Methods}

Focus group research has been used extensively in marketing studies, as this kind of qualitative group interviewing enables researchers to gain valuable insight into public opinion and perceptions (Morgan, 1997). It is possible to obtain in-depth information about perceptions and attitudes. Focus groups encourage group interaction and discussion; moderators are able to ask clarifying questions to seek a deeper understanding - a feature not possible in traditional surveys (Merriam, 1998).

Focus group research is based on facilitating a guided discussion on a particular topic with a group of individuals in an effort to listen and learn from their perceptions and opinions. The researcher develops the protocol and questions to guide discussion, organizes the logistics of the focus groups, and later analyzes the data for themes and patterns (Morgan, 1998).

This kind of study is concerned more with process and "probing the phenomena for a deeper understanding” than qualitative research methods (McMillan \& Schumacher, 2010). Because FNGLA had already invested in an outreach campaign with the creation of a brand name, logo, website, and select print materials, and because there were specific existing messages to test, it was deemed most appropriate to utilize a research methodology that allowed more in-depth explorations of individual response, attitudes, and knowledge. In order to test outreach messages, interviews are often found to be more effective because participants are able to explore concepts and messages more thoroughly (Kruger, 1994).

This study used a set of three focus groups comprised of representative members of the target audience of plant product consumers (six in total). A set of two focus groups were held in three geographically and demographically different regions of Florida in March 2010. These focus groups 
were held in Jacksonville, Orlando, and Miami; all sessions were conducted by graduate students and staff at the University of Florida PIE Center in Gainesville, Florida.

A market research firm in Gainesville was hired and used Computer Assisted Telephone Interviewing (CATI) telephone random digit dialing (RDD) sampling to qualify potential participants. Criteria used to select potential participants were a general interest in gardening, plants, or home improvement projects. Probability samples were generated using a predetermined sampling frame based on demographic variables for all participant groups.

In qualitative studies, addressing reliability and validity is much different than in quantitative studies, and requires a kind of redefinition (Golafshani, 2003). To ensure consistency (reliability) and accuracy (validity) of a qualitative study, the highest care must be taken when interacting with participants. When utilizing focus groups, it is necessary to be clear, open, and consistent during all of the sessions - the same moderator should be used, the same moderator's guide and prompts, the same technological tools, the same recording devices, and even the same note-takers if possible. For this study, all of these steps were taken to ensure consistency.

The moderator's guide was drafted and vetted through multiple parties to ensure clarity and relevance of questions. The researcher who authored the moderator's guide served as an assistant moderator and note-taker during the sessions. An unaided/aided technique was utilized during sessions, with directive questions that followed in order to prompt participants and encourage them to interact with each other to explore each specific topic.

In order to explore consumer awareness and usage of plants, participants were asked for what purpose they usually purchased plants (e.g. garden, gifts, beauty, as a replacement plant). To determine participants' opinions of plant characteristics most important to plant purchases, an interactive "Turning Point" exercise with visuals and scales was utilized. On a scale of 1-5 (1 being low and 5 being high), participants were asked to rate a series of plant characteristics. Responding to the question, "How do you select what plants you will purchase?" participants were given the following prompts: Quality, Healthy looking, Attractive/pretty, Native to the area, Affordable, Hearty, Fertilizer use, Pesticides use, Low maintenance, Recognizable or familiar, Not known to be invasive, Makes me feel good, Fits the landscape, Seasonal planting selection, Environmentally friendly, Colorful (leaves or flowers), and Brand. Participants were also asked about garden and landscape terms commonly used in the green industry in order to explore perceptions and cognitive shortcuts associated with the terms.

The data used in this study was derived from part of a larger study, which was sponsored by FNGLA and funded by the Florida Department of Agriculture and Consumer Services (FDACS). The focus of the larger study was message testing of a Florida-specific plant brand name, logo, website, and communication materials.

\section{Results}

Participants of six Florida focus groups were asked to articulate what they thought of when they heard certain words or terms. Demographically, the participants were very diverse. Occupations ranged from retired teachers, public relations/sales managers, stay-at-home-parents, students, builders, and even marketing professionals. All participants had an interest in gardening or home improvement, and were asked what came to mind when they heard the word "plant" and "garden"; where they most often hear these words; what they thought the actual meaning of these words were; and how the words made them feel. There were six groups total in the FNGLA sessions (in three

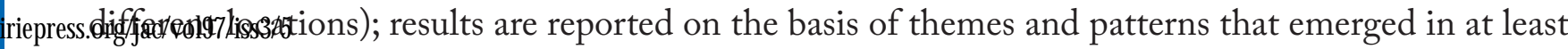


four or more of the six groups.

When asked about the word "plant," all six of the groups responded that it conjured images of something "living" or "growing." Participants in four of the six groups mentioned being outside, soil, or the earth. Participants in four of the six groups also stated that they hear the word "plant" most often at retail outlets (such as Lowes or Home Depot). Most groups responded that the meaning of the word "plant" depends on the context and use (verb, noun, place, thing). One said:

"[The word plant] could be taken a couple of different ways. I mean she said you've got to plant the field of vegetables or the plants on the table. Or there's harvest, you know. It could be interpreted a couple of different ways."

When presented with the word "garden," participants of all groups thought of food, vegetables, and flowers. One said:

"I would think that plants, most of the plants I see, they always grow something on them. It's cool, a lot of fruits and vegetables. Most of the ones I have in my yard are edible. It's solid."

Members of all groups mentioned work, resources or hobbies of the word "garden," such as, “something that's taken care of and paid a lot of attention to." Members of all six groups also brought up beauty, tranquility, or pride. One said:

"It's almost like looking at a page. You can look at someone's garden, and you can see the planning involved. That somebody's put flowers in a certain way, you know, the yard is perfect, the lawn is perfect, great level, and you look at it, and say, 'Hey, gee, this is a perfect garden.' Rather than looking at my yard, I call it a yard but there's spots here and spots there and I wouldn't even call it a garden. It's just a work in progress."

Participants in five of the six groups mentioned personal space or home. One participant articulated this by saying:

"I think of garden as my personal space. You come to my house and you say, 'Oh come look at my garden.' And so it's an extension of me, it's a place where I like to be. So the garden is very important to me."

Participants in five of the six groups hear "garden" most often while shopping or in advertisements. Participants in four groups hear "garden" most on television.

Of the word "landscape," all six groups felt the word depicted something that was large scale. One participant said:

"It's a lot of planning for landscape. It's not just cutting grass anymore. It's mulch and all the pretty stuff that they put in the yards."

Participants in all six groups thought of something manicured, designed, or very organized such as "expensive and constant maintenance." Participants of four groups mentioned the work or resources involved, and four of six groups thought of food or vegetables. 
When presented with the term "home landscape," members of all six groups brought up aesthetic appeal or beauty, and said that planning, design, and/or organization was needed; home landscape is the "curb appeal of the home." One summed this up by saying:

"Home landscaping seems a little bit larger scale. It seems like you're going to see something that's...in my garden, it's everything. You'll see orchids next to air plants; you'll see everything. But when you see home landscaping, you think that someone has actually made more structure."

Participants of five of the six groups thought of cost, resources or the work involved and mentioned residence or personal space, like "personal care of your property." Participants of four groups heard "home landscape" most often on advertisements, while shopping, or on the Internet.

Members in all six groups indicated that they most often purchase plants for beauty or decoration. Participants of five of the six groups had a specific function or purpose in mind when purchasing plants, such as vegetable plants for food or hedges for privacy. Participants of four of six groups brought up that they purchase plants for gifts or sentimental purposes.

In an interactive "Turning Point" exercise, participants are given an electronic "clicker" and asked to make individual decisions about how important certain plant attributes were to deciding whether or not they would purchase a particular plant. In this session, participants were asked to rate 17 different plant characteristics in regard to how important these characteristics are to plant purchases (see Table 1 below). Participants rated each characteristic on a Likert-type scale with the following choices: very important; important; neither important nor unimportant; somewhat unimportant; and not important.

Of the total participants, 72 percent selected a plant being "healthy looking" as a very important characteristic; 65 percent of participants thought a "quality" plant was very important. A plant "making me feel good" was very important to 57 percent of the participants, 52 percent of participants indicated that the plant being "durable" was very important, and 50 percent selected an "attractive or pretty" characteristics as very important to plant purchases.

When asked what plant characteristics are most important when selecting plants for purchase, plants being non-invasive came up often, and many groups discussed the importance of plants being "environmentally friendly." This was also reflected In the Turning Point exercise. One participant said:

“They're not native to South Florida and they're everywhere. Certain plants just take over and kill the native plants."

Many of the participants indicated that the brand of a plant was not important (Sixty-five percent of the participants responded that it was "not important." Twenty-five percent of participants responded that it was neither "important nor unimportant"). One participant summed up this pattern by saying:

"When I think of brands, it's more with clothing, and plants, it's more God's brand."

Many others were confused by the idea of a plant having a brand. Of those who identified with a plant brand, it was common for them to name a retail outlet (such as Lowe's or Home Depot), 
Table 1

Plant Characteristics Important to Consumer Purchase

\begin{tabular}{|c|c|c|c|c|c|}
\hline Plant characteristics & $\begin{array}{c}\text { Very } \\
\text { Important }\end{array}$ & Important & $\begin{array}{c}\text { Neither } \\
\text { important } \\
\text { nor } \\
\text { unimportant }\end{array}$ & $\begin{array}{l}\text { Somewhat } \\
\text { unimportant }\end{array}$ & $\begin{array}{c}\text { Not } \\
\text { important }\end{array}$ \\
\hline Healthy looking & $72 \%$ & $22 \%$ & $2 \%$ & $2 \%$ & $0 \%$ \\
\hline Quality & $65 \%$ & $30 \%$ & $2 \%$ & $0 \%$ & $0 \%$ \\
\hline Makes me feel good & $57 \%$ & $20 \%$ & $12 \%$ & $2 \%$ & $7 \%$ \\
\hline Durable & $52 \%$ & $27 \%$ & $15 \%$ & $5 \%$ & $0 \%$ \\
\hline Attractive/pretty & $50 \%$ & $40 \%$ & $5 \%$ & $5 \%$ & $0 \%$ \\
\hline Seasonal & $47 \%$ & $12 \%$ & $25 \%$ & $2 \%$ & $5 \%$ \\
\hline Non-invasive & $45 \%$ & $22 \%$ & $25 \%$ & $5 \%$ & $0 \%$ \\
\hline Fits landscape & $45 \%$ & $25 \%$ & $12 \%$ & $0 \%$ & $5 \%$ \\
\hline Low maintenance & $42 \%$ & $22 \%$ & $22 \%$ & $2 \%$ & $10 \%$ \\
\hline Environmentally Friendly & $42 \%$ & $17 \%$ & $12 \%$ & $5 \%$ & $5 \%$ \\
\hline Affordable & $42 \%$ & $27 \%$ & $17 \%$ & $5 \%$ & $7 \%$ \\
\hline Native to area & $37 \%$ & $22 \%$ & $22 \%$ & $10 \%$ & $7 \%$ \\
\hline Pesticide use & $35 \%$ & $22 \%$ & $20 \%$ & $10 \%$ & $12 \%$ \\
\hline Fertilizer use & $32 \%$ & $12 \%$ & $25 \%$ & $12 \%$ & $15 \%$ \\
\hline Colorful & $25 \%$ & $27 \%$ & $22 \%$ & $10 \%$ & $15 \%$ \\
\hline Familiar/recognizable & $5 \%$ & $7 \%$ & $30 \%$ & $12 \%$ & $45 \%$ \\
\hline Brand & $2 \%$ & $7 \%$ & $25 \%$ & $5 \%$ & $65 \%$ \\
\hline
\end{tabular}

Note: Percentages are based on total participants from all six focus groups

\section{Conclusion, Discussion, and Recommendations}

Regarding objective one, "exploring consumers' perceptions of plants, gardening, and landscaping," focus group participants for this study tended to have a more diverse perception of "plant" than "garden," so long as the context was clear. The terms "landscape" and "home landscape" were understood by participants to denote a "larger scale" than a garden or inclusive property care.

For the purposes of marketing a plant brand that includes many varieties of plants, the use of the word "plant" may be more effective than the word "garden," as participants tended to think of "garden" as vegetables and/or flowers only, and the word was perceived as non-indicative of other kinds of plants sold. Because the Florida Garden Select brand would market a wide variety of plants, it may be more effective to utilize the word "plant" in the brand. It is not recommended that the terms "landscape" or "home landscape" for marketing be used in this case, as participants in every group were reminded of the work or resources involved or required. These terms did not elicit the same cheerful qualities as "plant" or "garden" did.

For those marketing state-specific brands, it is important that schema theory and the Model of Causality be understood and utilized in regard to language selection and focus group participants' perceptions of "plant," "garden," "landscape," and "home landscape," as the potential purchaser's previous knowledge, perceptions of the language and associated product, and influence of the external environment has a large impact on the decision to buy the product. If consumers do not understand 
that by "garden" Florida Garden Select means a wide variety of plants, the brand may not be successful unless the perception or cognitive shortcut can be altered.

Regarding objective two, "determining what types of messages consumers' best respond to in relation to purchasing plants," the majority of participants did not think that the brand of a plant was important at all. The target audience of potential consumers chose healthy-looking, quality, and "makes me feel good" as the most important characteristics for purchasing plants. Potential consumers also felt that a plant being durable, attractive, non-invasive, and "environmentally friendly" was important.

Yue, Hurley, and Anderson (2009) found that consumers' willingness to pay for plants decreases when the plants are labeled as invasive and increases when plants are labeled as native. Since a plant's being "non-invasive" was a significant finding, it is recommended that this issue be addressed up front by demonstrating that the selected plants have been selected using specific criteria that include their thoroughly studied lack of invasive qualities.

Because so many of the participants alluded to the brand of a plant as being "not important" when selecting plants for purchase, it will be essential to successful marketing to showcase the brand in more unconventional ways than merely putting a sticker or tag on the pot of the plant. Participants rarely remembered the name of a brand of a plant, and many thought only of the store where they were purchased.

The Theory of Planned Behavior has great applicability for the marketing of a state-specific plant brand. If potential consumers are knowledgeable about the Florida Garden Select branded plant being tested specifically for their home state and are motivated to support it, know that it is a desired social norm (to support local/state products), know where the products are available, and think that their purchase will benefit them or their community, they will be more likely to purchase a Florida Garden Select branded plant.

The Elaboration Likelihood Model can also prove to be a relevant addition to a state-specific plant brand marketing campaign. If the FNGLA (or any other agricultural commodity organization aiming to market a state specific brand) can ensure that marketing messages and communications make clear the relevance of the brand upon the product, perhaps by emphasizing the importance of supporting locally grown products, it may be more salient, and thus become more important to potential consumers. Also, consumers will be more likely to utilize the "shortcut" peripheral route of processing the information if it came from a trusted source, so the credibility of the organization and its members should also be accentuated. Credibility is most often built over time, though participants in this study regarded the University of Florida, landscape professionals, horticulturalists, and commodity groups as "very credible," so that may be indicative of an existing high level of trust in the industry.

In conclusion, in order for plant brand marketing campaign to be successful, the organization should consider the plant characteristics mentioned above (healthy-looking, quality, and "makes me feel good"') and 1) strive to achieve these characteristics with the products they are marketing, and 2) emphasize these plant characteristics in a marketing campaign. From the results of this study, it seems that the product (plants) may not easily lend itself to a marketable brand in the eyes of potential consumers. For this reason, it is recommended that the marketing campaign focus on the special attributes of the plants that ensure consumer satisfaction and potential brand loyalty due to a quality product. 


\section{References}

Adelaja, A.O., Nayga, R.M. Jr., \& Schilling, B. (1994). New Brunswick, NJ. Returns to the Jersey Fresh Promotional Program- An Econometric Analysis of the Effects of Promotion Expenditures on Agricultural Cash Receipts in New Jersey. Report submitted to the Division of Markets New Jersey Department of Agriculture, Trenton, New Jersey.

Ajzen, I. (2002). Behavioral Interventions based on theory of planned behavior. Retrieved 6/12/2011 from http://www.unix.oit.umass.edu/ ajzen.

Ajzen, I. (1991). The Theory of Planned Behavior. Organizational Behavior and Human Decision Process, 50, 179-211.

Bagnara, G. (1996). Brand Name and Added Value in Horticultural Products: Analysis of Consumer Perception. Working paper, Center for International Food and Agricultural Policy, Department of Agronomy Economics., University of Minnesota.

Bandura, A. (2004). Model of Causality in Social Learning Theory. In A. Freeman, M. Mahoney, P. Devito, and D. Martin (Eds.), Cognition and psychotherapy (25-44). New York, NY: Springer Publishing Company.

Collart, A, J., Palma, M.A. \& Hall, C.R. (2010). Branding Awareness and Willingness to Pay Associated with the Texas Superstar ${ }^{\mathrm{TM}}$ and EarthKind ${ }^{\mathrm{TM}}$ brands in Texas. Horticultural Science, 45(8), 126-1231.

Florida Department of Agriculture and Consumer Services. (2004). Fresh From Florida. Florida Agricultural Promotional Campaign (FAPC). Retrieved on June 12, 2011 from http://www. florida-agriculture.com/marketing/fapc_membership.htm

Florida Department of Agriculture and Consumer Services Division of Marketing. (2004). Florida Seafood and Aquaculture. Retrieved on June 6, 2011 from http://www.fl-seafood.com

Florida Nursery, Landscape, and Growers Association. (2011). Florida Garden Select. Retrieved June 2, 2011, from http://www.fngla.org/community-programs/florida-garden-select/

Frewer, L.J, Howard, C., Hedderley, D., \& Shepherd, R. (1997). The Elaboration Likelihood Model and Communication about Food Risks. Risk Analysis, 17(6), 759-770.

Golafshani, N. (2003). Understanding reliability and validity in qualitative research. The Qualitative Report, 8(4), 597-606.

Glaser, B. (1965). The constant comparative method of qualitative analysis. Social Problems, 12 (4), 436-445. 
Govindasamy, R. (2003). The Economic Impact of the Jersey Fresh State Marketing Program. Paper provided by Rutgers University, Department of Agricultural, Food and Resource Economics. Retrieved June 15, 2011 from: http://ideas.repec.org/p/ags/rutdps/36728.html\#provider

Govindasamy, R., Italia, J. \& Thatch, D. (1998). Consumer Awareness of State-sponsored Marketing Programs: An Evaluation of the Jersey Fresh Program. Journal of Food Distribution Research, 29 (3), 7-15.

Govindasamy, R., \& Nayga, R. (1996). Characteristics of Roadside Stand Operations in New Jersey and a Profile of the Customers who Frequent Them. Paper presented at the 1996 North American Farmers' Direct New Marketing Conference, February 22-24, Saratoga Springs, New York.

Kruger, R.A. (1994). Focus Groups: A Practical Guide for Applied Research. Sage Publications: Thousand Oaks, California.

Koelemeijer, K., Leutscher, K.J. \& Stroeken, J.J.G. (1993). Branding of Horticultural Products: An Application to Pot Plants. Acta Horticulturae, 340, 325-332.

Lillywhite, J. Allison, M.C. \& Rodriguez, A.G. (2005). Regional Branding in a Global Marketplace. New Mexico Chile Task Force. College of Agriculture and Home Economics, Cooperative Extension Service, Agricultural Experiment Station Report No. 21.

McMillan, J.H. \& Schumacher, S. (2010). Research in Education: Evidence-Based Inquiry (7th ed). Upper Saddle River, New Jersey: Pearson.

Merriam, S.B. (1998). Qualitative Research and Case Study Applications in Education. Jossey Bass: San Francisco, California.

Morgan, D.L. (1997). Focus Groups as qualitative research. Thousand Oaks, CA: Sage Publications.

New Jersey Department of Agriculture. (2006). Jersey Fresh. Retrieved February 10, 2011 from http://www.state.nj.us/agriculture/divisions/md/prog/jerseyfresh.html

Neisser, U. (1976). Cognition and reality: principles and implications of cognitive psychology. San Francisco: W.H. Freeman.

Petty, R.E. \& Cacioppo, J.T. (1986). The Elaboration Likelihood Model of Persuasion. Advances in Experimental Social Psychology, 19, 123-162.

Reichel, S. (2009). Cognitive principles, critical practice: Reading literature at university. Vienna University Press. 
Rumelhart, D. E. (1980). Schemata: The building blocks of cognition. In R. J. Spiro, B. C. Bruce, \& W. E Brewer (Eds.). Theoretical issues in reading comprehension: Perspectives from cognitive psychology, linguistics, artificial intelligence, and education (pp. 33-58). Hillsdale, NJ: Erlbaum.

Stegelin, F., Turner, S., \& Knight, P. (2001). Proceedings from Southern Nursery Association Research Conference 2001: State Plant Promotion Programs: Histories and Perspectives. Ackworth, GA.

Yue, C., Hurley, T. \& Andersen, N. (2009). Do native and invasive labels affect consumer willingness to pay for plants? Paper presented at the Agricultural and Applied Economics Association. AAEA \& ACCI Joint Annual Meeting, Milwaukee, WI, 26-28 July. 